\title{
USEFULNESS OF SEROLOGY FOR THE EVALUATION OF TRYPANOSOMA CRUZI TRANSMISSION IN ENDEMIC AREAS OF CHAGAS' DISEASE
}

\author{
Roberto Chuit', Elisabet Subias 2 , Analia C. Pérez 2 \\ Irene Paulone 2 , Cristina Wisnivesky-Colli2 and Elsa L. Segura2
}

\begin{abstract}
Thirteen communities from 7 Argentinian provinces were selected for the evaluation of serology as an indicator of transmission of Chagas disease. Of the communities appraised, 6 did not have a history of previous treatment with insecticides and 7 had received sporadic or continuous insecticide treatment. The inhabitants of $20 \%$ of the houses of each locality were studied by serology. The samples were obtained by finger pricking and $50 \mu$ lofblood were mixed with $150 \mu$ l of $50 \%$ glycerine solution in tissue culture media to be assayed by Indirect Hemagglutination and Indirect Immunofluorescence tests. In untreated areas, the prevalence of infection in infants $0-4$ years old was $17.5 \%$, reaching to over $22 \%$ for the $5-9$ year old group, and to $33.3 \%$ in $10-14$ year old individuals. The prevalence in treated and surveyed areas was $2.6 \%$ in $0-4$ year old children, $5.4 \%$ in 5-9 year old and $6,2 \%$ in 10-14 year old youngsters. The differences between both areas were statistically significant $(p<0.005)$. This study favors serology as a valid indicator for the evaluation of transmission of Chagas disease in rural areas.
\end{abstract}

Key-words: T. cruzi transmission. Prevention and control. Field study. Serodiagnosis.

Chagas' disease produced by infection with $T$. cruzi, is widely disseminated through the Americas 17 . The triatomine vector of $T$. cruzi may lodge in human dwellings, and can be found from Rio Colorado, in Northern Mexico, to the Parallel $42^{\circ}$ South in Argentina and Chile 27 .

The suggestion of controlling domestic triatomine by spraying houses with insecticides as a control measure of disease transmission, was advanced at the beginning of the forties in the Continent 1020 . In Argentipa, the first steps were undertaken around 1940 and later on, in the mid fifties, control campaigns were iniciated in some provinces 424 . In 1962 the programme extended over 9 provinces, and in the seventies the whole country was under control. Activities involved insecticide application in dwellings and

1. Servicio Nacional de Chagas. Secretaria de Salud, Ministerio de Salud y Acción Social de la Nacion. Córdoba, Argentina.

2. Instituto Nacional de Diagnóstico e Investigación de la Enfermedad de Chagas "Dr Mario Fatala Chabén" (INDIECH) Secretanía de Salud-Ministerio de Salud y Acción Social de la Nación. Buenos Aires, Argentina.

This work was supported by the Secretary of Health of the Argentinian Ministry of Health and by UNDP/WORLD BANK/WHO Special Programme for Research and Training in Tropical Disease (TDR).

Postal Address: INDIECH, Av. Paseo Colón 568 CP: 1063 Telex 25064 Coopre Ar, Buenos Aires, Argentina.

Recebido para publicação em 23/8/88. serological control of blood to be transfused 23 . On that occasion, the National Control Agency, the Servicio Nacional de Chagas (ChCA) and the Instituto Nacional de Diagnóstico e Investigación de la Enfermedad de Chagas (INDIECH) were created. The first to care for the control of the insect population and the second, to control the inter-human transmission of Chagas' disease 23 .

The activity carried out for the control of vectors consists mainly of insecticide spraying of domiciles during the chemical attack phase 1319 . After the attack phase, periodic entomological evaluations are recommended, to be carried out by means of the $\mathrm{man} / \mathrm{hour}$ method, as part of the so called "classical surveillance" method in treated houses ${ }^{19}$. These actions, performed by trained personnel of the Control Agency are costly as they demand 60 minutes of work of skilled men per house to be completed. Houses found infested, are sprayed with insecticide 1319 .

Serology has been one of the powerful tools to study Chagas' disease, and to develop control strategies, at first by the use of Complement Fixation and nowadays by the use of Hemagglutination techniques among others, which has permitted is to define endemic areas in the Continent ${ }^{912}$. Serology has been also used by several groups as an alternative method of retrospective evaluation for the status of Chagas' disease transmission in populations of endemic areas, such as in studies carried out in Argentina and the rest of the Continent 823 . It was demonstrated that the 
prevalence of Chagas' disease in 18 year old men in Argentina decreased from $10.3 \% 7$ in 1968 to $5.9 \%$ in $1981^{23}$. Such a decrease included 18 year old men born in 1963, and showed the effect that the control Program may have had on transmission after 19 years of application.

One of the limitations of serology for field work is related to blood sampling. At present, a new procedure is being applied, which enables collection of capillary blood samples by finger puncture, rendering unnecessary, for the next 30 days after collection, any special laboratory conditions and allowing the storage of samples at room temperature and humidity 25 .

The serological study of children is relevant because it would permit the detection over short periods of the effects of the control actions.

This paper outlines a proposed scheme for serological studies in rural communities, which could be used as a prospective tool for the evaluation and planning of control campaigns. For that purpose all the inhabitants of each house selected in thirteen areas from seven Argentinian Provinces, were serologically studied. Serological results were correlated with the activities carried out by the Argentinian Chagas disease Control Agency (ChCA).

\section{MATERIALS AND METHODS}

This study was performed from December, 1983, to May, 1985 and involved thirteen rural villages from thirteen counties of seven Argentinian provinces (Figure 1). These selected localities were similar in the number and type of population, housing, geographical distribution and socio-economical conditions.

The areas were selected according to the belowmentioned criteria, and with data obtained from records of the ChCA.

Category 1) Areas without chemical treatment.

Areas which had not received insecticidal treatment up to the date when the study began.

Category 2) Areas chemically treated

a) Surveyed: areas chemically treated in the attack phase and surveyed by the Control Programme more than once in a determined period.

b) Recently treated, or areas where no surveillance activities were made for a long period of time (Table 1).

Sampling procedures: The houses selected were considered as the sampling unit, studying all their occupants. According to cartographic information obtained from the Primary Health Care Programme (PHC), an average of $15 \%$ to $20 \%$ of the houses

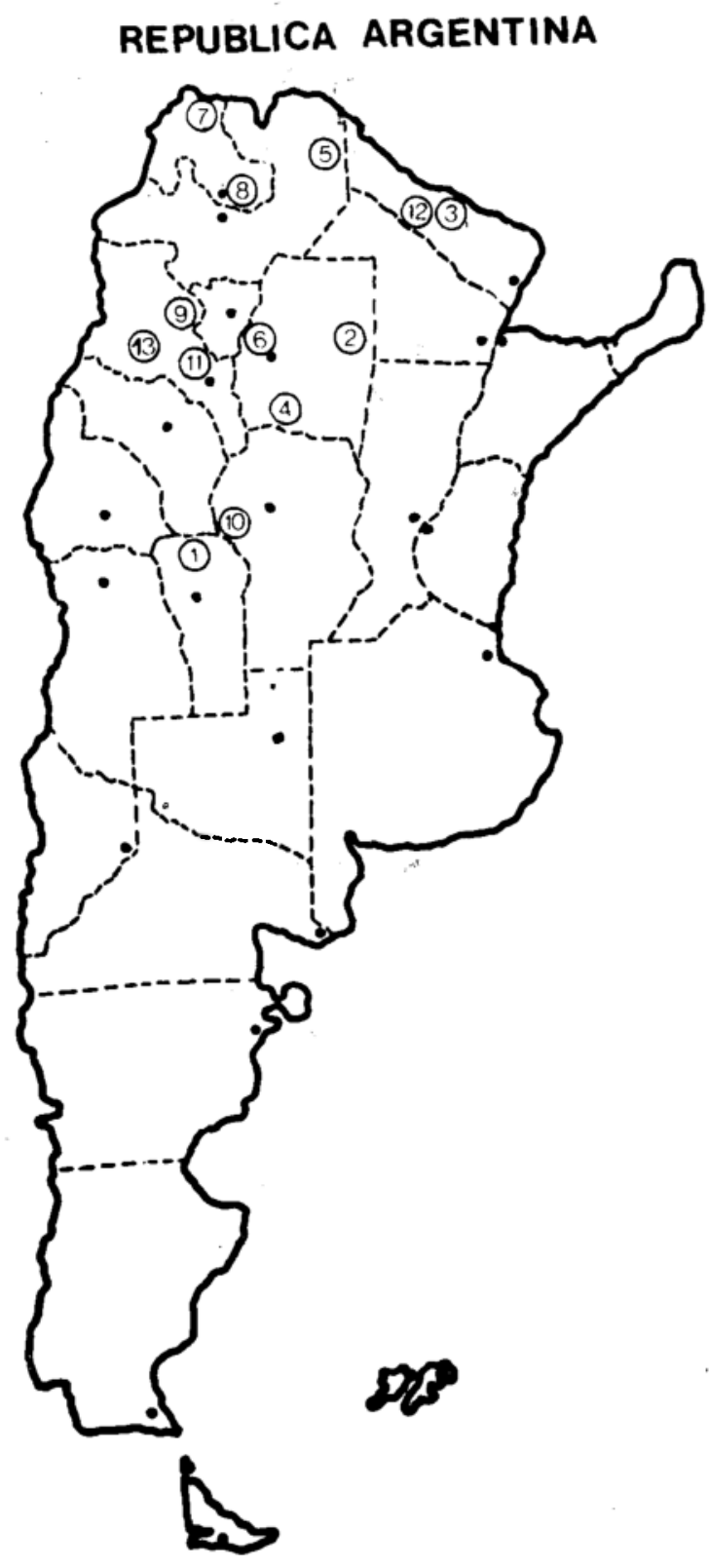

Figure 1 - Geographical distribution of the Argentinian rural localities studied: 1. Caldén, Retamo, Ayacucho, San Luis; 2. Amamá, Moreno, Santiago del Estero; 3. San Martin 2, Patiño, Formosa; 4. Los Telares, Quebrachos, Santigo del Estero; 5. Santa Victoria, San Martin, Salta; 6. Sotelos, Rio Hondo, Santiago del Estero; 7. Yavi Chico, Yavi, Jujuy; 8. Labatón-Acheral, San Pedro, Jujuy; 9. Paclin, El Alto, Catamarca; 10. Chancani, Pocho, Cordoba; 11. Pirquitas-Huaycano, Ambato, Catamarca; 12. San Martin 1, Patiño, Formosa; 13. Pajonal, Pomán, Catamarca. 
Chuit R, Subias S, Pérez AC, Paulone I, Wisnivesky-Colli C, Segura EL. Usefulness of serology for the evaluation of Trypanossoma cruzi transmission in endemic areas of Chagas' disease. Revista da Sociedade Brasileira de Medicina Tropical 22: 119-124, Jul-Set, 1989

inhabited in the whole area were selected representing one of five of the houses existing in the area 1516 .

The first house to be surveyed was selected at random and then a systematic sampling procedure was used. Those people absent at the beginning of the study were included upon their return.

Sample collection and serological study: Blood samples were collected by pricking a fingertip with a disposable sterile blade, collecting $50 \mu \mathrm{l}$ with a gauged capillary tube, and mixing the sample with $150 \mu \mathrm{l}$ of the preservative contained in a polypropylene tube with an hermetic rubber cap 25 . These tubes were placed in 60 -tube trays each one contained in a woodenbox suitable for handling. Blood samples collected in the field were sent by mail to INDIECH to be analysed. Indirect

Table 1- Distribution of serological prevalence for T. cruzi infection grouped by area, age-group and category of insecticide treatment - Argentina 1983-1985.

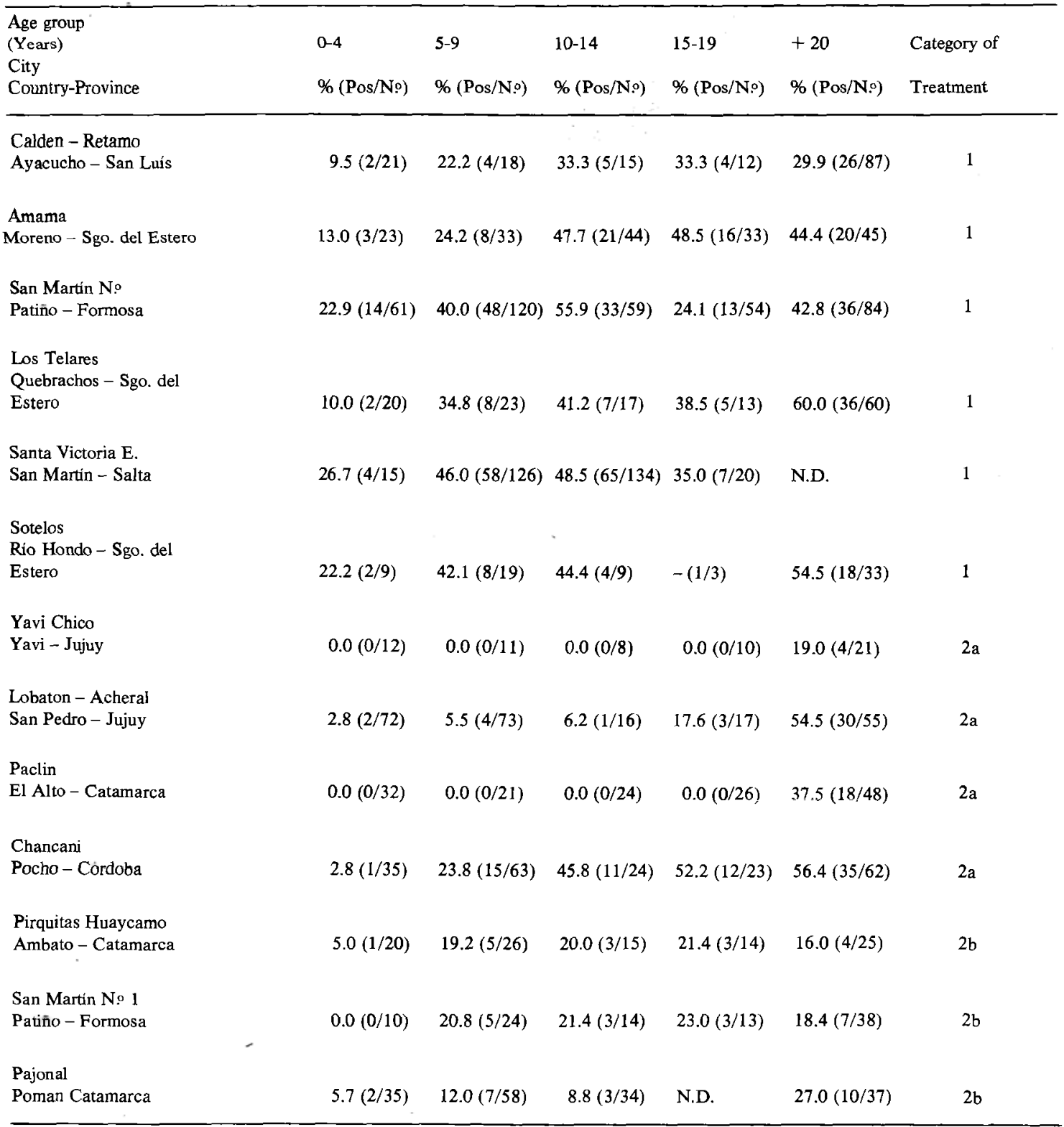

N.D. Not Done: $1=$ without treatment $2 a=$ with treatment and continuous surveillance $2 b=$ with treatment and no regular surveillance. 
Chuit $R$, Subias S, Pérez AC, Paulone I, Wisnivesky-Colli C, Segura EL. Usefulness of serology for the evaluation of Trypanossoma cruzi transmission in endemic areas of Chagas' disease. Revista da Sociedade Brasileira de Medicina Tropical 22: 119-124, Jul-Set, 1989

Hemagglutination (IHA) ${ }^{26}$, and Indirect Immunofluorescence (IFI) ${ }^{2}$ reactions, specific for anti $T$. cruzi antibodies were used as the serologic tests 6 and non coincident results between both reactions were verified by the Enzyme Immunossay (ELISA) using $T$. cruzi epimastigote membrane antigens ${ }^{22}$. IHA and IFI provided a $99.5 \%$ of specificity when performed together at the minimum reactive dilution of $1: 32^{5}$. The initial serum dilution was 1:16 in all cases due to the $1: 4$ dilution of the blood in the preserver. Reactivity of blood samples with the preservative had up to a $97 \%$ correlation with identical samples of serum obtained from venopuncture as was previously described 25 .

\section{RESULTS}

A total of 2226 blood samples were collected from patients of both sexes with ages ranging from 6 months to 93 years of age. Serological analysis showed 670 positive results (30.09\%).

Serological results of the studied samples are presented in Table 1, grouped by the origin of the area: city, county or province; by the age groups of the population; and by the modality of application of the chemical treatments performed in the houses.

All areas which had not received insecticidal treatment (Category 1 ) showed similar results in terms of prevalence: in children aging from 0 to 4 years, higher than 10\%; an increasing prevalence of more than $22.2 \%$ in children from 5 to 9 years of age, reaching its maximum level in children aging from 10 to 14 years. No significant differences were found among prevalence rates shown by the 10 to 14 years old group with respect to children 15 to 19 years of age or 20 years or older $(p>0.1)$. For instance, the results for the San Martin 2 population, in Patino, in the province of Formosa, a locality of this category, are presented in Figure 2.

The prevalence rates observed in areas treated and continuously surveyed for household reinfestations by triatomines (Category $2 \mathrm{a}$ ) are similar to those observed in the cities of Lobaton and Acheral, San Pedro, in the Province of Jujuy (Figure 2). In these areas, children aged from 0 to 4 years, showed a prevalence of $2.6 \%$ while those from 5 to 9 years of age had a prevalence rate of $5.4 \%$; those from 10 to 14 years showed a rate of $6.2 \%$, which rose to $17.6 \%$ in children from 15 to 19 years of age and to $54.5 \%$ in people older than 19 years of age.

Within Category $2 \mathrm{~b}$ in the locality of Pajonal, in the Province of Catamarca, where control activities were not continuous, children 5-9 years of age showed an increased prevalence rate of $12 \%$ compared to children 10 to 14 years of age $(8.8 \%)$, but these differences are not statistically significant $(\mathrm{p}>0.1)$.

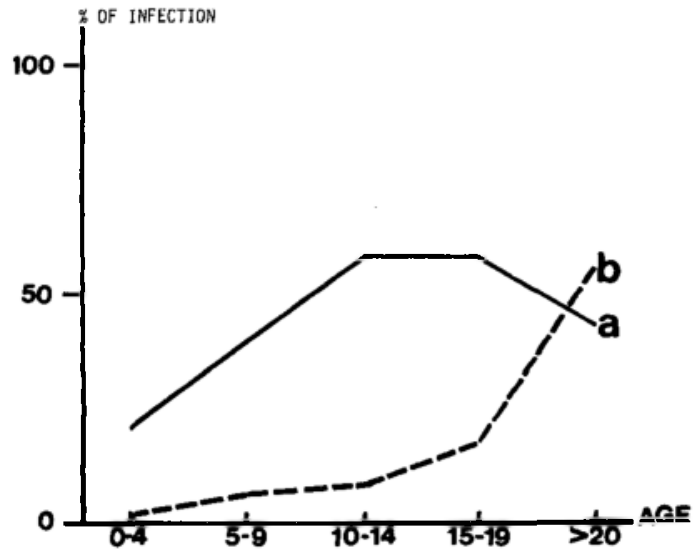

Figure 2 - Serological prevalence to $\mathrm{T}$. cruzi infection according to age-group; a) (__ San Martin 2, Formosa: without chemical treatment; b) (--.-.--) Lobatón y Acheral, Jujuy: with chemical treatment and continuous surveillance.

Serological reactivity of those populations which were chemically treated with insecticides compared to non-treated areas are analysed in Figure 3. A significant difference was observed between both

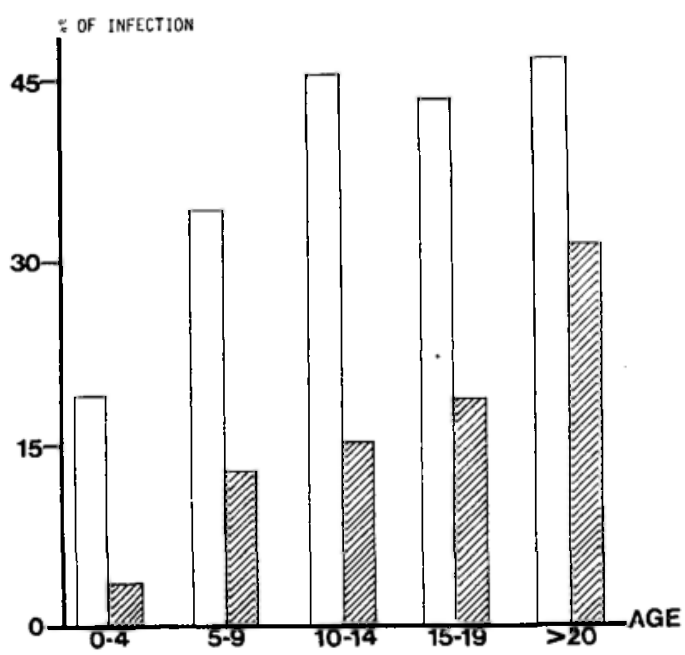

Figure 3 - Distribution of average serological prevalence to $\mathrm{T}$. cruzi infection obtained in Argentine in 6 locatities without chemical treatment (blank columns) and 7 localities with chemical treatment (striped columns).

regions, where children from 0 to 4 years of age belonging to chemically treated areas show an average prevalence rate of $2.3 \%$, whereas children of the same age living in non-treated areas show a prevalence rate of $17.5 \%(\mathrm{p}<0.005)$. 
Chuit R, Subias S, Pérez AC, Paulone I, Wisnivesky-Colli C, Segura EL. Usefulness of serology for the evaluation of Trypanossoma cruzi transmission in endemic areas of Chagas' disease. Revista da Sociedade Brasileira de Medicina Tropical 22: 119-124, Jul-Set, 1989

\section{DISCUSSION}

The serological prevalence rates for Chagas' disease in rural areas without insecticidal treatment shown in this study are coincident with the relative values obtained by Rosenbaun and Cerisola at the end of the fifties ${ }^{21}$ and confirm those obtained by Bonet et al $^{3}$. In all cases serological prevalence rates increase with the age of the individuals, reaching their maximun in the age groups older than 40 .

Data obtained confirm previous findings in Argentina which show that the highest risk of infection, in areas of active transmission, is below 10 to 14 years of age, reflected on the fact that at least $50 \%$ of the total infected population is already infected at this age ${ }^{321}$. These data are coincident among others with those found in Bambui, Brasil ${ }^{11}$ and Venezuela 18.

The results shown here present, according to Rosenbaum, "Information about what happened in the past with individuals studied in the present", where each individual under study represents a cross section of the different stages of the evolutive cycle of the disease ${ }^{121}$.

This assertion becomes demonstrated by the increasing prevalence with steeper slopes for areas without treatment than for chemically treated regions.

In those areas where chemical treatment was performed, a prevalence rate of $2.3 \%$ was found in children 0 to 4 years of age, whereas in non-treated areas a prevalence rate of $17.5 \%$ was found in this age group, evidencing the effects of control measures against domestic triatomine with promotion of community participation. Once more the use of chemical control actions ensures the interruption of $T$. cruzi human transmission and the surveillance appears necessary to maintain this condition in the long-term. These assertions are reflected in locality of Chancani, Córdoba, where the area was sprayed every 4-5 years, and in Lobatón where surveillance was performed continuously from 1966 up to the present time by the current programme of health of the province of Jujuy. In both localities interruption of the transmission was successfully achieved, in the early eighties in the former and at the end of the sixties in the latter.

Research work on the serological prevalence of $T$ cruzi infection in children gives information about the status of transmission at the moment of sample collection, about its history and its future evolution, the latter, depending on the actions to be implemented.

In chemically treated areas where continuous entomological surveillance activities were carried out, serological prevalence rates of $T$. cruzi infection in children up to 4 years of age tended to decrease, whereas this trend in those areas where no surveillance measures were taken was not observed. Thus serology is a suitable indicator of the state of the transmission of infection by $T$. cruzi in rural communities before or after any control campaign intervention ${ }^{14}$.

Control Programmes current surveillance and evaluation activities are based on the use of the results of their own entomological surveys as indicators of the state of transmission. The extent of the endemic area and control programme constraints concerning trained personnel and its mobilization to the areas makes it difficult to achieve regular evaluations by this methodology. Serology, on the other hand, would allow the undertaking of surveys in the hands of local trained human resources, becoming a useful tool to help in a Control Programme current activities.

Control Programmes have, at present, a variety of improved and new technologies compared with those available at their origins that open new possibilities. This fact would permit the beginning of a gradual change in the philosophy of control Programmes and the use of new laboratory's methodologies, like serology in the hands of their own welltrained field agents, this would effectively accomplish the scope and objectives of the programmes.

In summary, the results of prevalence of $T$. cruzi infection obtained from serological sampling performed in rural areas from thirteen departments of seven endemic provinces for Chagas' disease in Argentina, qualify serology as an appropiate technology, easilyavailable, economic, and a sensitive indicator of the status of the transmission, providing a tool for the evaluation of control actions performed and the planning of future activities.

\section{RESUMO}

Treze comunidades de 7 províncias argentinas foram escolhidas para avaliação de sorologia como indicador da transmissão da Doença de Chagas. Das comunidades mencionadas, seis não tinham história prévia de tratamento com inseticidas e sete tinham recebido tratamento esporádico ou continuado.

Vinte por cento dos moradores das casas de cada localidade foram estudados por sorologia. As amostras foram obtidas por punção da ponta do dedo e 50 microlitros de sangue foram misturadas com 150 microlitros de uma solucão conservadora de glicerina a $50 \%$ em meio de cultivo, para serem estudados por hemaglutinacão indireta, e imunofluorescência indireta. Nas áreas não tratadas a prevalência da infecção em crianças de 0-4 anos foi de 17,5\% chegando a mais de $22 \%$ para as de 5-9 anos e a 33,3\% no grupo 10-14 anos. A prevalência nas áreas tratadas e sob vigilância foi de $2.6 \%$ em crianças de 0-4 anos, 5, 4\% anos de 5-9 anos e de 6, 2\% em jovens de 10-14 sendo as diferenças entre os dois tipos de áreas estatisticamente significativas $(<0,005)$. 
Chuit R, Subias S, Pérez AC, Paulone I, Wisnivesky-Colli C, Segura EL. Usefulness of serology for the evaluation of Trypanossoma cruzi transmission in endemic areas of Chagas' disease. Revista da Sociedade Brasileira de Medicina Tropical 22: 119-124, Jul-Set, 1989

Este estudo propõe a sorologia como um indicador válido para a avaliação da transmissão da Doença de Chagas em áreas rurais.

Palavras-chaves: Transmissão de $T$. cruzi. Prevenção e controle. Estudo de campo. Sorodiagnóstico.

\section{ACKNOWLEDGEMENTS}

We wish to thank, Dr Mirta Carlomagno for her editorial assistance. Adolfo Contreras and Victor Vigil gave valuable practical assistance in the field.

\section{REFERENCES}

1. Acquatella H, Catalioti F, Gomez-Mancebo JR, Davalos V, Villalobos L. Long-term control of Chagas' disease in Venezuela: effects on serologic findings, electrocardiographic abnormalities, and clinical outcome. Circulation 76:556-562, 1987.

2. Alvarez M, Cerisola JA, Rohwedder RW. Test de inmunofluorescencia para diagnóstico de la enfermedad de Chagas. Boletin Chileno de Parasitologia 23: 4-8, 1968.

3. Bonet AH, Cichero JA, Kushnir E. Grand JC, Segura EL. Estudio epidemiológico sobre la enfermedad de Chagas-Mazza en comunidades rurales de la provincia de Córdoba. La Semana Medica 133: 581, 1968.

4. Bravo CR, Herrera de Bravo BR. Enfermedad de Chagas-Mazza en la República Argentina. Ed. Aruman, Catamarca, 1981.

5. Camargo ME, Segura EL, Kagan IG, Souza JM, Carvatheiro JR, Yanovsky JF, Guimarāes MC. Three years of collaboration on the standardization of Chagas' disease serodiagnosis in the Americas: an appraisal. Bulletin of the Pan American Health Organization 20: 233-244, 1986.

6. Cerisola JA, Martini GW, Alvarez M. Actualizaciónes sobre la enfermedad de Chagas n 2. Diagnóstico por el Laboratorio. Ministerio de Bienestar Social. Subsecretaria de Salud Pública, Buenos Aires, Argentina, 1972.

7. Cichero JA, Bonet AH, Grand JC, Rossini AS. Investigación de la enfermedad de Chagas-Mazza en los ciudadanos clase 1944 convocados para el servicio militar por el Centro de Reconocimientos. II Jornadas Entomoepidemiológicas Argentinas, Córdoba 2:5-10, 1967.

8. Coura JR, Pereira JB. A follow-up evaluation of Chagas' disease in two endemic areas in Brazil. Memórias do Instituto Oswaldo Cruz (Rio de Janeiro) 79 (suppl.): 107-112, 1984

9. Dias E, Laranja FS, Nery-Guimarães F, Brant TC. Estudo preliminar de inquéritos sorológicos-eletrocardiográficos em populações não selecionadas de zonas não-endêmicas e de zonas endêmicas de Doença de Chagas. Revista Brasileira de Malariologia e Doenças Tropicais 5:205-210, 1953.

10. Dias E, Pellegrino J. Alguns ensaios com o "gammexane" no combate aos transmissores da doença de Chagas. Brasil Médico 62: 185-191, 1948.

11. Dias JCP. Doença de Chagas em Bambuí, Minas Gerais, Brasil. Estudo clínico-epidemiológico a partir da fase aguda, entre 1940 e 1982 . Tese de Doutorado. Universidade Federal de Minas Gerais, Belo Horizonte, Minas Gerais, 1982.

12. Freitas JLP. Inquérito preliminar sobre moléstia de Chagas no Município de Cajuru, Estado de São Paulo, Brazil. O Hospital (Rio de Janeiro) 29:155-165, 1946.

13. Gualtieri J, Carcavallo R, Becker D. Normas técnicas y procedimientos para la lucha química contra el vector. Servicio Nacional de Chagas: Normas coordinadas. Chagas 1:29-45, 1983.

14. Hoff R, Todd CW, Maguire JH, Piesman J, Mott KE, Mota EE, Sleigh A, Sherlock IA, Weller TH. Serologic surveillance of Chagas' disease. Annales de la Société Belge de Medicine Tropicale 65 (suppl.):187-196, 1985.

15. MacMahon B, Pugh TF. Principios y métodos de epidemiologia. La Prensa Médica Mexicana, México, 1983.

16. Neghme RA, Ramán PJ. Método epidemiológico aplicado a la investigación de Enfermedad de Chagas en Chile. Revista Goiana de Medicina 5:323-337, 1959.

17. OMS. Informe de un grupo de estudio para analizar las estrategias de control de la enfermedad de Chagas. Publicación Científica n.o 195, 2-8 de Sept, OPS-OMS, Washington DC, 1969.

18. Pifano FC. Epidemiologia de la Enfermedad de Chagas en Venezuela. Simpósio Internacional sobre Enfermeđad de Chagas. Buenos Aires, Argentina p. 217-223, 1972.

19. Programa Nacional de Lucha contra la Enfermedad de Chagas-Mazza, periodo 1963-1966. Ministerio de Asistencia Social y Salud Pública. Dirección de enfermedades transmisibles, Buenos Aires, Argentina p. 64, 1964.

20. Romaña C. Abalos W. Desinsectación integral de las viviendas rurales. Primeras Jornadas Entomoepidemiologicas Argentinas, Salta Argentina p. 335-337, 1959.

21. Rosenbaum MB, Cerisola JA. Epidemiologia de la enfermedad de Chagas en la Republica Argentiua. $O$ Hospital 60:75-124, 1961.

22. Segura EL, Bua J, Rosenstein de Campanini A, Subias E, Esteva M, Moreno M, Ruiz AM, Monoclonal antibodies against the flagellar fraction of epimastigotes of Trypanosoma cruzi; Complement-mediated lytic activity against trypamastigotes and passive immunoprotection in mice. Immunology Letters 13:165-171, 1986.

23. Segura EL, Pérez AC, Yanovsky JF, Andrade J, Martini GJW. Decrease in the prevalance of infection by Trypanosoma cruzi (Chagas' disease) in young men of Argentina. Bulletin of the Pan American Health Organization 19:252-264, 1985.

24. Soler CA. Campaña piloto de erradicación de la vinchuca. Villa Mazán. La Rioja Subsecretaria de Salud Publica. La Rioja, Argentina, 1958.

25. Subias E, Yanovsky J, Alvarez M, Segura EL. Conservation of blood samples for epidemiological research on Chagas' disease. Journal of Protozoology 30 (Abstract): $164,1983$.

26. Yanovsky JF, Aberbach S. Reacción de hemaglutinación para el diagnóstico de la enfermedad de Chagas, Técnica Yanosvsky-Aberbach. Ministerio de Acción Social, Secretaria de Estado de Salud Pública, Resistencia, Provincia de Chaco. Resolución no 218p. 77, 1977.

27. Zeledón R. Vectores de la enfermedad de Chagas y sus caracteristicas ecofisiológicas. Interciencia 8: 384-389, 1983. 